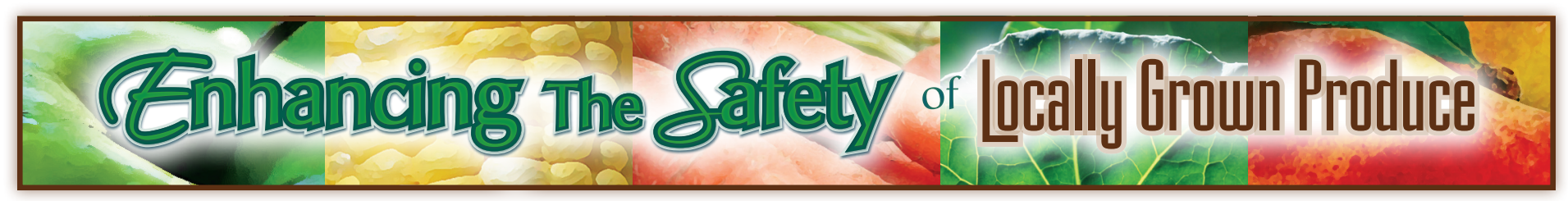

\title{
Water Ulse
}

W ater is an essential part of life and an essential part of any farm. It is necessary for growing produce and often for cleaning produce before it is sold. Water may also be used to protect crops from frost or to apply fertilizers or pesticides. Ensuring that you have clean water on the farm for these uses is an important part of minimizing contamination by disease-causing microorganisms called pathogens. Water can carry pathogens such as Giardia, Cryptosporidium, Norovirus, Salmonella, and E. coli O157:H7 that can cause people to become ill if it comes in contact with the harvestable part of the crop. Having water tested for generic E. coli levels, an indicator of water quality, helps to ensure that the water you use is safe..

\section{Jrrigation water}

Irrigation water usually comes from either wells or surface water sources such as ponds or streams. Municipal water is sometimes used, but this is often an expensive option. Although municipal water will minimize contamination risk, it is usually not feasible to use for irrigation. Potable well water (water safe for drinking) is also a good choice. Surface water and well water not of drinking quality can be used with certain precautions during crop production.

Well water - Wells can be either drilled or bored. Bored wells are usually shallow from 20 to 50 feet deep and have a larger diameter wellhead of two to three feet. They are sometimes cased with concrete and have concrete caps. Because these wells are shallow, if not properly constructed and maintained, they can have a higher potential for contamination than a drilled well. Older bored wells are vulnerable to surface water that can carry pathogens moving down the outside of the well casing or through gaps in the concrete casing created by roots from shrubs or trees.

Drilled wells are usually deeper and, depending on the geology of the area, penetrate into hard rock. Because these wells are deeper, they are usually less vulnerable to contamination; however, any well that is poorly constructed and maintained can provide a conduit for pathogens into the water supply.

\section{The wellhead location is also important for minimizing risk.}

$\diamond$ Do not locate wellheads in areas that receive runoff from roads, heavy animal agriculture areas, manure storage areas, or composting areas.

$\diamond$ Do not locate wellheads within 150 feet of waste lagoons, septic tanks or drainfields.

Surface water - Ponds, streams, lakes, rivers and man-made reservoirs can be used for irrigation, but this water poses a high level of risk for contamination because it is open to the environment. Be very aware of what is upstream from where water is drawn. Upstream areas that are heavily grazed or have animal access to the water source increase the risk of contamination. Take these precautions when using surface water.

$\diamond$ Exclude animals including waterfowl and pets from ponds used for irrigation water.

$\diamond$ Avoid using surface water after heavy rainfall until the sediments have settled, and the water is clear again. Research has shown pathogens are higher in stormwater and in sediments.

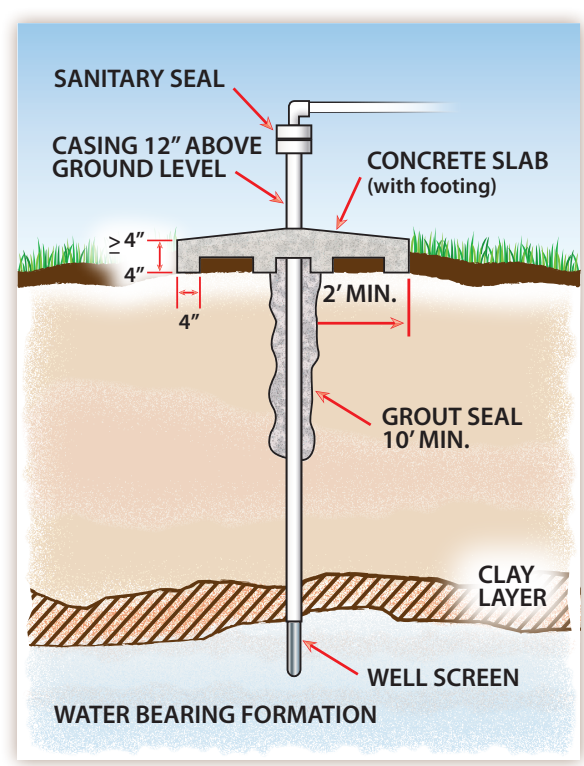

A Diagram showing proper drilled well construction. Notice the concrete slab around the wellhead that prevents surface water from moving down the outside of the well casing. This type of slab is critical for both drilled and bored wells to prevent contamination.

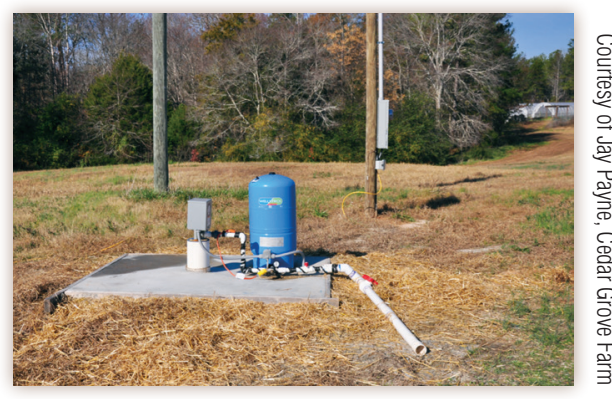

A This well has a concrete pad to help minimize the risk of contamination. 
$\diamond$ Use drip irrigation where practical. In general, drip is preferred to overhead irrigation because the water is less likely to come in contact with harvestable portions of the crop. This is particularly true when using surface water sources.

$\diamond$ Consider irrigating early in the day, if overhead irrigation must be used, so sunlight and drying can reduce the level of pathogens.

$\diamond$ Waiting several days between the last overhead application of irrigation water and harvest of the crop can reduce risk but is not an absolute guarantee of safety.

Be aware that standing water in a field can be a source for pathogens, so take care to minimize its contact with the surface of produce.

\section{Jrigation methods}

$\diamond$ Irrigation methods can also affect the level of risk from agricultural water. Typically, produce is irrigated using overhead irrigation, furrow or flood irrigation or drip irrigation. Overhead irrigation has a higher risk for contaminating produce since water from the sprinkler comes in direct contact with the harvestable portion of the plant. Furrow or flood irrigation where water may be running through the growing area or standing in the growing area is somewhat less risky than overhead irrigation, but water may still contact the harvestable portion of the plant through splashing. Drip irrigation which includes subsurface, trickle and under canopy irrigation has the lowest level of risk of contamination. Except for root crops, water dispensed through drip irrigation is unlikely to come in direct contact with the harvestable parts of the plant. It also lowers the risk of plant diseases and improves water use efficiency by lessening evaporation. There are some precautions to take when irrigating produce.

$\diamond$ Have each surface water source and well water source you are using tested for generic $E$. coli to determine whether or not they meet the microbial water quality standard specified in the Produce Safety Rule. Standards will be discussed in more detail in the Water Testing section of this document.

$\diamond$ There are free on-line water calculators on the University of California Davis website and the University of Arizona website. These can be accessed by doing an Internet search for UC Water Calculator or for Arizona Water Calculator. When you enter your water test results into the calculator, it automatically calculates whether your water meets or exceeds the standards. If the contamination level of your water exceeds the standard, the calculator may advise waiting for a period of time up to four days between the last application of water and harvest of the crop to help minimize food safety risk.

\section{Nater testing}

The most important thing that can be done to ensure the safety of irrigation water is testing for generic $E$. coli bacteria, an indicator of fecal contamination. Extension agents can provide containers and teach you how to take a clean sample.

It is a good idea to choose a certified water testing laboratory that can perform one of the methods accepted by FDA to meet the water requirements under the FSMA Produce Safety Rule and let them know that is what you need.

If you are using municipal water for irrigation, no testing is required unless you suspect a problem. Obtain a copy of your municipality's annual water report or certificate of compliance and keep it in your records. Inspect your water delivery system on the farm at least once a year to look for broken emitters, leaking pipes, pooling or other problems that could lead to contamination.

$\diamond$ Test well water at least once a year by taking at least one sample and close to the time of harvest.

$\diamond$ Test surface water more often. A best practice is to take 5 or more samples close to the time of harvest from each surface water source.

$\diamond$ Keep the records of the water tests to document that you have managed your farm water as safely as possible. 


\section{Nater standards}

The Produce Safety Rule established nationwide standards for water used during production and for post-harvest water. If you need to or want to comply with the Produce Safety Rule you must meet the following requirement:

The water that comes in contact with the harvestable part of the crop during production must have a geometric mean of 126 or less colony forming units (CFU) of generic E. coli per $100 \mathrm{ml}$ of water and a statistical threshold value (STV) of 410 or less CFU of generic E. coli per $100 \mathrm{ml}$. This requires additional testing that is not outlined in this fact sheet.

It is also important to remember that buyers may require more frequent testing than what is required under the Produce Safety Rule. Keep the records of your water tests to document that you have managed your farm water as safely as possible. If you have never had your water tested, it is a good practice to do so, even if you are exempt from the Produce Safety Rule.

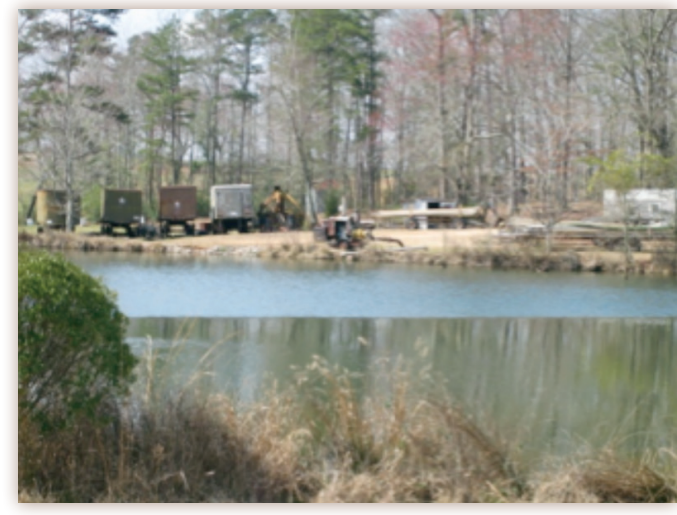

A Surface water ponds can be used for irrigation with precautions.

If well water test results indicate high counts of generic E. coli, inspect the well for cracks or other damage that could allow in surface water. Once construction or maintenance problems are resolved, the well can be cleaned using shock chlorination. County Extension agents can provide information on the proper steps for this.

If surface water tests indicate high counts of generic E. coli, evaluate potential upstream sources of contamination. Using a filter or a small settling basin can sometimes help reduce coliforms. Be very cautious about how you use the water until you can correct the situation. Irrigation water can be treated using UV light, filters or ozonator units. Any chemicals used to treat water must be EPA registered and labeled for the intended use, just like pesticides are labeled for particular uses. As of December 2018, no chemical sanitizers are labeled for use to decrease fecal coliforms in irrigation water. This may change. An extensive list of sanitizers can be accessed by conducting an Internet search for Produce Safety Alliance Sanitizer List. Keep records of any treatments or corrective actions that you take to solve problems with your water.

\section{Post-harvest water}

Water used at the time of harvest or after harvest must meet the standard of no detectable generic $E$. coli in 100 $\mathrm{ml}$. This includes water that is used for rinsing produce, washing hands, making ice that will come in contact with the harvested produce and cleaning and sanitizing surfaces that will come in contact with the produce.

\section{For more information on water standards, compliance dates for those under the Produce Safety Rule and up-to-date information regarding Produce Safety Rule requirements, visit the FDA website at www.fda.gov and search for Produce Safety Rule.}

